\title{
Change of sensory characteristics and some quality parameters of mixed milk and cocoa spreads during storage up to 180 days
}

\author{
Jovanka V. Popov-Raljić ${ }^{1}$, Jovanka G. Laličić-Petronijević ${ }^{2}$ Etelka B. Dimić ${ }^{3}$, Vladimir S. Popov ${ }^{4}$, Vesna B. \\ Vujasinović ${ }^{5}$, Ivana V. Blešić ${ }^{1}$, Milijanko J. Portić ${ }^{1}$ \\ ${ }^{1}$ University of Novi Sad, Faculty of Science, Trg Dositeja Obradovića 3, 21000 Novi Sad, Serbia \\ ${ }^{2}$ University of Belgrade, Faculty of Agriculture, Nemanjina 6, 11080 Belgrade - Zemun, Serbia \\ ${ }^{3}$ University of Novi Sad, Faculty of Technology, Bulevar Cara Lazara 1, 21000 Novi Sad, Serbia \\ ${ }^{4}$ University of Novi Sad, Faculty of Agriculture, Trg Dositeja Obradovića 8, 21000 Novi Sad, Serbia \\ ${ }^{5}$ College of Professional Studies in Management and Business Communication, Mitropolita Stratimirovića 110, Sremski \\ Karlovci, Serbia
}

\begin{abstract}
The main role of milk and milk products in the technology of confectionery products (chocolates, caramele-candy products, dairy products, spreads, etc.) is to increase the nutritional value of the final product and to influence some sensory characteristics of quality (appearance, consistence/texture, flavor). In this study, mixtures of milk and cocoa spreads of a new composition with increased content of milk components were produced, and then assessed for sensory quality traits, peroxide value, free fatty acid content and the content of heavy metals (lead, cadmium and copper) during storage from 30 to 180 days at room temperature $\left(18-20^{\circ} \mathrm{C}\right)$. The samples were evaluated using the analytical-descriptive sensory analysis (point system) with description of the dominant properties (appearancecolor, surface gloss, consistence-spreadability, dynamic property of melting, the consistence in the oral cavity-oiliness and flavor-odor and taste). The results of sensory analysis were statistically analyzed using two-way analysis of variance MANOVA, LSD and Levene's test. Based on the obtained results, it can be concluded that the composition of mixtures of milk and cocoa spreads significantly affects all characteristics, whereas the storage time significantly affects the appearance, consistence, i.e., spreadability, and taste of the product.
\end{abstract}

Keywords: sensory analysis, spreads, peroxide value, free fatty acid, heavy metals, storage.

\author{
SCIENTIFIC PAPER \\ UDC 663.914/.916:66 \\ Hem. Ind. 67 (5) 781-793 (2013) \\ doi: 10.2298/HEMIND120903004P
}

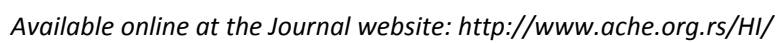

According to the rulebook on quality and other demands for cocoa products, chocolate products, products similar to chocolate and confectionery spreads [1], spreads are obtained by processing sugar, milk and dairy products, vegetable fats and other food products. Regarding the consistence, they are produced as: spreadable, bars, granules or "crispy" spread-cream products [2]. At the market they can be found as dairy cream-products, containing at least $12 \%$ of non-fat dry matter of milk (calculated on the whole product), mixtures of milk-spreads products, cacao-spreads products and others. Spreads are concentrated food with high energetic (about $2.272 \mathrm{~kJ} / 100 \mathrm{~g}$ ) and nutritive value, and are favourite in the nutrition of children and sportists, but also of healthy grown-ups [3]. Condensed milk, milk powder, partially skimmed and skimmed milk powder are mostly used in the confectionery industry. Besides, milk crumb, "block milk", anhydrated milk fat,

Correspondence: J.G. Laličić-Petronijević, University of Belgrade, Faculty of Agriculture, Nemanjina 6, 11080 Belgrade - Zemun, Serbia.

E-mail: jovankal@agrif.bg.ac.rs

Paper received: 3 September, 2012

Paper accepted: 9 January, 2013 whey powder, cheese powder, whey powder and serum proteins are also used [4-6].

The main physical and functional characteristics that affect the quality of milk powder are: powder structure, distribution of powder particles dimensions, density of particles, air incorporated in and between the particles, burnt particles, reconstruction ability, hygroscopy, heat-stability and emulsification stability. The reconstruction stability includes several characteristics of powder: solubility and moistening ability [7]. Milk powder used in the confectionery industry contributes to the nutritive value of the product, and improves the consistence (texture), odor taste and stability $[6,8]$. Whey powder contains proteins with highvaluable amino acids, milk sugar - lactose, vitamins and mineral components from the milk. Besides the improvement of flavor, whey powder also affects better texture, better stability of the product. The main role of milk products is to increase the nutritive value of confectionery products, and to influence some sensory characteristics - flavor, color, texture and others $[5,6]$. Condensed whey, i.e., syrup-like product with 80 to $85 \%$ of dry matter, can be also used in the confectio- 
nery industry. When condensed whey is used, the colour of the final products (caramele) is darker [9]. Serum proteins are mainly used to achieve the appropriate nutritive value of the final product, and to improve some functional characteristics: foam or gel formation, production and stabilization of emulsion $[4,10]$. A number of authors $[2,11,12]$ cite that sugar can be completely or partially replaced with sweeteners (fructose, maltitol, lactitol and xylitol) in accordance with the rulebook on quality and conditions of use of additives in food products and other demands for additives and their mixtures [1].

As one of the main constituents of chocolate products, with content in spreads between 25 and 40\%, fats are an important raw material that affect the behaviour of spreads during the processing, and a number of quality characteristics of the final product taste, melting, mouth-feel, consistence/texture, other physical characteristics of these products, as well as their nutritive value $[13,14]$. Due to economic reasons, cocoa butter is often replaced with special vegetable fats, i.e., cocoa butter substitutes and/or replacers. These fats are obtained by different technological processes from natural oils and fats and oils like palm oil [15], cocoa-fat, rapeseed oil, palm seed oil, etc. [13], and can completely or partially replace the traditional chocolate fat - cocoa butter. These fats can be found at the market, with different names, kind of raw material, way of processing and recommended use.

The tempering of products is not necessary when cocoa buter substitutes and replacers are used [16]. Nowadays, the opinion of the consumers is that hydrogenated oils and fats, containing saturated or trans isomers of unsaturated fatty acids, are undesirable in the nutrition [16]. Besides having a negative effect on the cardio-vascular system [17], the trans fatty acids are also related to the development of some types of carcinomas, type 2-diabetes, alergies and asthma in children and thrombosis [13]. Therefore, hydrogenated fats are partially replaced with vegetable oils in the formula of nutritively high-valuable products. The use of cocoa powder results in lower energetic value of the product, however, this ingredient is a source of fiber and mineral components. Cocoa powder resembles chocolate, due to specific cocoa flavor and therefore is an ingredient in a number of products. Non-fat cocoa products, with fat content $<8 \%$, enables better mixing with special fats [3]. Spreadable cream products should have certain sensory quality characteristics, i.e., smooth and shiny surface, soft consistence, i.e., spreadability, and characteristic flavor. Spreadable consistence should remain in the temperature interval from 8 to $20-22^{\circ} \mathrm{C}$. Investigation of rheological characteristics of domestic commercial spreads has shown that they express pseudo-plastic behaviour [14]. The mentioned products are characterized by rich creamy, milky-chocolate taste, with a light flavor of roasted hazelnut $[12,14,18]$ or added peanut [19]. Petkovic et al. [12] dealt with sensory analysis of cocoa spreads with sucrose, as well as those with full or partial replacement of sucrose with maltitol, in which they have evaluated the following sensory properties: shape, color, surface, texture, chewiness, taste and odor.

The main goal of this paper was to produce new products - spreads, under semi-industrial conditions, of appropriate composition and stability, without antioxidants and preservation agents, from mixtures of: defatted (skimmed) milk powder, whey powder and their combinations, hydrogenated vegetable fat (trans fatty acids $<10 \%$ ) and refined sunflower oil, cocoa-powder and hazelnut. The other aspect was the sensory evaluation of the obtained spread i.e. acceptability (appearance, texture/consistence, flavor) and investigation of some quality parameters important for safety of the products.

\section{MATERIALS AND METHODS}

In this study, correction of the standard industrial recipe for mixtures of milk and cocoa spreads was performed in order to obtain better sensory acceptability of the final products, as well as improved composition (increased content of dairy products, the use of cocoa powder with reduced amount of fat).

\section{Preparation of samples}

The basic raw materials for the production of milk and cocoa-cream products were skimmed powdered milk and whey powder (obtained from Mlekara Subotica, Subotica); hydrogenated vegetable fat (trans fatty acids $<10 \%$ ) and refined sunflower oil (Dijamant, Zrenjanin); cocoa powder (Centroproizvod, Belgrade); roasted dehulled hazelnut (Florida Bel, BelgradeZemun); powdered sugar and vanilla sugar (Centroproizvod, Belgrade); defatted soybean flour and soy lecithin (Sojaprotein, Bečej). All raw materials were produced in Serbia. The roasted and dehulled hazelnut was ground to obtain hazelnut pasta. With the addition of skimmed milk powder, whey powder, powdered sugar, a part of vegetable fat/oil, cocoa-powder, soybean flour, a pastose cream mass was obtained. At the end, the remaining fat/oil, lecithin and vanilla sugar were added. The prepared cream-mass was milled and homogenized in the colloid mill (Frima-Rheinfelden, Germany).

The size of the largest particles in the final product was from 30-50 $\mu \mathrm{m}$. The samples were packed in appropriate glass packagings (200 $\mathrm{ml}$ glass jars) and stored at room temperature up to 180 days.

Sample 1. Sugar, $20 \%$ skimmed milk powder (min $8.5 \%$ non-fat dry matter of milk), hydrogenated vege- 
table fat, refined sunflower oil, cocoa powder with reduced cocoa-butter content (min. $2.5 \%$ dry non-fat cocoa solids), soybean flour, emulsifier - lecithin, vanilla sugar.

Sample 2. Sugar, $15 \%$ skimmed milk powder (min $8.5 \%$ non-fat dry matter of milk), hydrogenated vegetable fat, cocoa powder with reduced content of cocoabutter (min. $2.5 \%$ dry non-fat cocoa solids), hazelnut paste, soybean flour, emulsifier - lecithin, vanilla sugar.

Sample 3. Sugar, $10 \%$ skimmed milk powder, $5 \%$ whey powder, refined sunflower oil, hydrogenated vegetable fat, cocoa powder with reduced cocoa-butter content (min. $2.5 \%$ dry non-fat cocoa solids), hazelnut paste, emulsifier - lecithin, vanilla sugar.

Sample 4. sugar, $12 \%$ skimmed milk powder, refined sunflower oil, hydrogenated vegetable fat, cocoa powder with reduced content of cocoa-butter (min. 2.5\% dry non-fat cocoa solids), emulsifier - lecithin, hazelnut paste, vanilla sugar.
Sample 5. Sugar, $20 \%$ whey powder, hydrogenated vegetable fat, refined sunflower oil, emulsifier - lecithin, hazelnut paste, cocoa powder with reduced cocoa-butter content (min. 2.5\% dry non-fat cocoa solids), vanilla sugar.

\section{Sensory analysis of quality}

Ten experienced accessors evaluated the sensory quality of mixtures of milk and cocoa spreads [20,21]. The appearance (colour, surface gloss), consistence/ /texture (spreadability, dynamic melting property and oiliness), flavor (odor and taste) and overall sensory quality of mixed milk and cocoa spreads were evaluated (Table 1).

Twenty individual samples were evaluated from every group of samples, $1,2,3,4$ and $5(n=100)$. The sensory evaluation was performed in a laboratory [22] at room temperature $18-20{ }^{\circ} \mathrm{C}$. The scoring system (from 1.00 to 5.00 ) was applied for the sensory eva-

Table 1. Sensory evaluation of spreads quality

\begin{tabular}{|c|c|c|c|c|}
\hline Property & Characteristic & Coefficient of signifficance & Description & Score \\
\hline \multirow[t]{5}{*}{ Appearance } & \multirow{5}{*}{$\begin{array}{l}\text { Visually evaluated } \\
\text { characteristic of: } \\
\text { - colour } \\
\text { - surface shine }\end{array}$} & \multirow[t]{5}{*}{2.00} & Excellent colour, smooth shiny (bright) surface & 5.00 \\
\hline & & & Unexceptionable color, surface smooth and shiny & 4.00 \\
\hline & & & $\begin{array}{l}\text { Poorer color, unsufficiently shiny surface, inside air- } \\
\text { bubbles }\end{array}$ & 3.00 \\
\hline & & & Partially uniform of shade and gloss of surface color & 2.00 \\
\hline & & & Nonuniform shade and gloss of surface color & 1.00 \\
\hline \multirow[t]{10}{*}{ Texture } & \multirow{5}{*}{$\begin{array}{l}\text { Visually evaluated } \\
\text { characteristic of: } \\
\text { - consistence } \\
\text { - spreadability }\end{array}$} & \multirow[t]{5}{*}{4.00} & Characteristic consistence and spreadability & 5.00 \\
\hline & & & Very good consistence and spreadability & 4.00 \\
\hline & & & Good consistence and spreadability & 3.00 \\
\hline & & & Inappropriate consistence and spreadability & 2.00 \\
\hline & & & Unsatisfactory consistence and spreadability & 1.00 \\
\hline & $\begin{array}{l}\text { Orally evaluated dynamic } \\
\text { characteristic of melting }{ }^{a} \text {, }\end{array}$ & \multirow[t]{5}{*}{6.00} & $\begin{array}{l}\text { Characteristic melting and characteristic oily coating of } \\
\text { oral cavity }\end{array}$ & 5.00 \\
\hline & \multirow[t]{4}{*}{ - oiliness } & & Very good melting and oily coating of oral cavity & 4.00 \\
\hline & & & Good melting and good oily coating of oral cavity & 3.00 \\
\hline & & & $\begin{array}{l}\text { Inappropriate melting and insufficient oily coating of } \\
\text { oral cavity }\end{array}$ & 2.00 \\
\hline & & & $\begin{array}{l}\text { Unsatisfactory melting and insufficient oily coating of } \\
\text { oral cavity }\end{array}$ & 1.00 \\
\hline \multirow[t]{10}{*}{ Flavor } & $\begin{array}{l}\text { Olfactorily evaluated } \\
\text { characteristic of: }\end{array}$ & \multirow[t]{5}{*}{2.00} & $\begin{array}{c}\text { Characteristic, pleasant odor of certain (distinct) note } \\
\text { that can be identified }\end{array}$ & 5.00 \\
\hline & \multirow[t]{4}{*}{ - odor } & & Characteristic, pleasant odor & 4.00 \\
\hline & & & Bland pleasant but unsufficiently intensive odor & 3.00 \\
\hline & & & Unsufficiently intensive, undefined odor & 2.00 \\
\hline & & & Without odor, atipycal odor note & 1.00 \\
\hline & \multirow{5}{*}{$\begin{array}{l}\text { Orally evaluated dynamic } \\
\text { characteristic of: } \\
\text { - taste }\end{array}$} & \multirow[t]{5}{*}{6.00} & Characteristic, pleasant archaic taste & 5.00 \\
\hline & & & Characteristic pleasant taste & 4.00 \\
\hline & & & Bland pleasant but unsufficiently intensive taste & 3.00 \\
\hline & & & Unsufficiently expressed taste or tasteless & 2.00 \\
\hline & & & No taste or distasteful & 1.00 \\
\hline
\end{tabular}

a Dynamic melting characteristic - contact with skin or in the mouth, and the term time/intensity refers to time necessary for the change of state and feeling in the mouth (melting in the mouth - without chewing) 
luation, with possibility of use half or a quarter point. A weight coefficient (WC) was determined for each quality characteristic (appearance, texture/consistence and flavor) in order to correct (by multiplying) the obtained score. The coefficients depend on the influence of certain characteristics on the overall quality and are ballanced in such a manner that their sum is 20 . The sum of individual scores (points) is a complex parameter representing the total sensory quality, and is expressed as the \% of maximal possible quality. Deviding this value with the total sum of weight coefficient (WC = 20), the weighted mean score is obtained, representing the total sensory quality of the assessed spreads.

The quality category was determined depending on the range of marks: products which were evaluated with less than 2.5 points, were considered as unsatisfactory, i.e., as inacceptable; scores within limits 2.5-3.5 characterized good quality products, $3.5-4.5$ very good quality and $4.5-5$ - excellent products $[5,23]$.

The data obtained in the investigations performed in this study were analyzed by descriptive and analytical statistics. Basic parameters of the descriptive statistics included calculations of the arithmetic mean values, and variabiltiy parameters of the investigated properties included determinations of standard deviations $(S d)$ and variation coefficients $(C V)$ expressed in percents.

For analytical statistics (for evaluation of sensory determinations) the two factorial analyze of variance MANOVA was applied, with the first factor being the storage time, and the second one - the composition of the evaluated samples of mixtures of milk and cocoa spreads, as well as the LSD test (test of the least significant differences of pairs). For finding out if the prerequisites for variance analysis methods are justified, homogeneities of variances were determined using Levene's test [24].

\section{Determination of peroxide value $-P V$}

The PV of the fat phase was determined by standard iodometric method [25], used for the determination of oxidation products of oils and fats. The method is based on the reaction between the hydroperoxides and peroxides with $\mathrm{HI}$ acid, which is formed from $\mathrm{KI}$ in acidic media. The amount of separated $\mathrm{I}_{2}$ is determined by titration with $\mathrm{Na}_{2} \mathrm{~S}_{2} \mathrm{O}_{3}$. The peroxide value is expressed as milimoles per $\mathrm{kg}$.

\section{Determination of free fatty acids content - FFA}

The acidity of fat phase was determined by alkalometric titration method [26]. The chloroform solution of fat, obtained by cold extraction [27], was titrated with standard $\mathrm{KOH}$ solution till the change of indicator color. The used alkali amount is directly proportional to the amount of free fatty acids. The acidity is expressed as the content of free fatty acids calculated on $\%$ of oleic acid.

\section{Determination of heavy metals content by atomic absorption spectrometry}

The content of bioresidues, i.e. lead, cadmium and copper in the investigated spread samples, was determined by atomic absorption spectrometry (AAS) on Spektrolab AA 202 (England). The heavy metals were determined at different wavelengths, lead $-217 \mathrm{~nm}$, cadmium $-228.8 \mathrm{~nm}$ and copper $-324.26 \mathrm{~nm}$.

The determinations are in accordance with the rulebook on amount of pesticides, metals and metaloides and other toxic substances, hemiotherapeutics, anabolics and other substances that can be present in food products [28].

\section{RESULTS AND DISCUSSION}

The changes of induvidual sensory properties (appearance: color, surface shine; texture: consistence, spreadability, melting and oiliness; flavour: odor and taste) of mixtures of milk and cocoa spreads during 180 days of storage are shown in Figures 1-5. The overall sensory quality during 180 days of storage is presented in Figure 6.

The mixture of milk and cocoa spread - sample 1 was of excellent sensory quality, during the first month after the production $\left(X_{m}=4.59\right.$, or $91.80 \%$ of the maximal possible quality). The appearance - color, surface gloss of sample 1 got somewhat lower mark, $X_{\mathrm{m}}=$ $=4.15$, since the dark (cocoa) and light (milk) phase were mixed (Figure 1). During the storage period of up to 180 days at room temperature, the overall sensory quality of sample 1 decreased by one quality category, i.e., to very good, $X_{\mathrm{m}}=4.28$, or $85.70 \%$ (Figure 6 ) primarily due to moderate spreadability (Figure 2) and dynamic melting characteristics, as well as noticeable oiliness and sandiness (Figure 3). According to data presented earlier [11], sandiness may appear when lactitol (a substitute for saccharose) is used, since the proper granulation of this sweetener is somewhat hard to achieve.

The total sensory quality of fresh sample 2 was excellent, $X_{m}=4.81$, or $96.3 \%$ of the maximal possible quality (Figure 1). On the basis of sensory evaluation for the 0-30 days period, the score for sensory characteristic - appearance of sample 2 was the highest of all examined samples $-X_{m}=4.95$ (Figure 2). Furthermore, the dynamic characteristic of melting in the mouth was excellent and without oiliness (Figure 3 ). The visually evaluated consistence/texture and spreadability are also characteristic for spreadable cream products. The surface of this product was firm, smooth and moderately shiny. No sandiness was detected. The sample 2 was characterized by a distinct, pleasant milky flavor. 

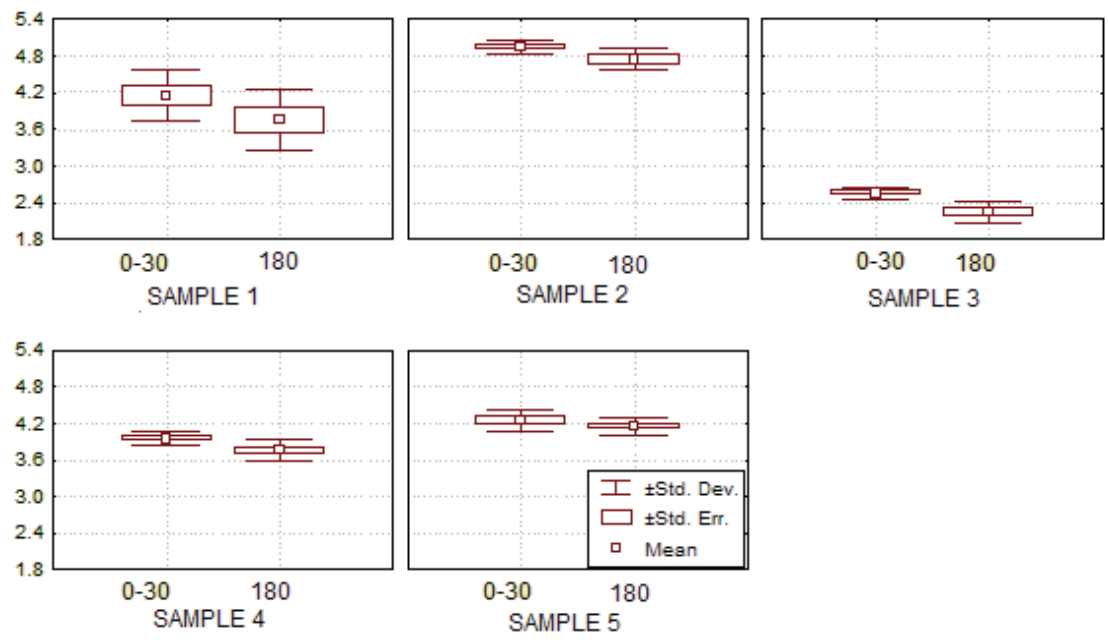

Time of keeping and storage (days)

Figure 1. Box-plots for sensory characteristic-appearance.
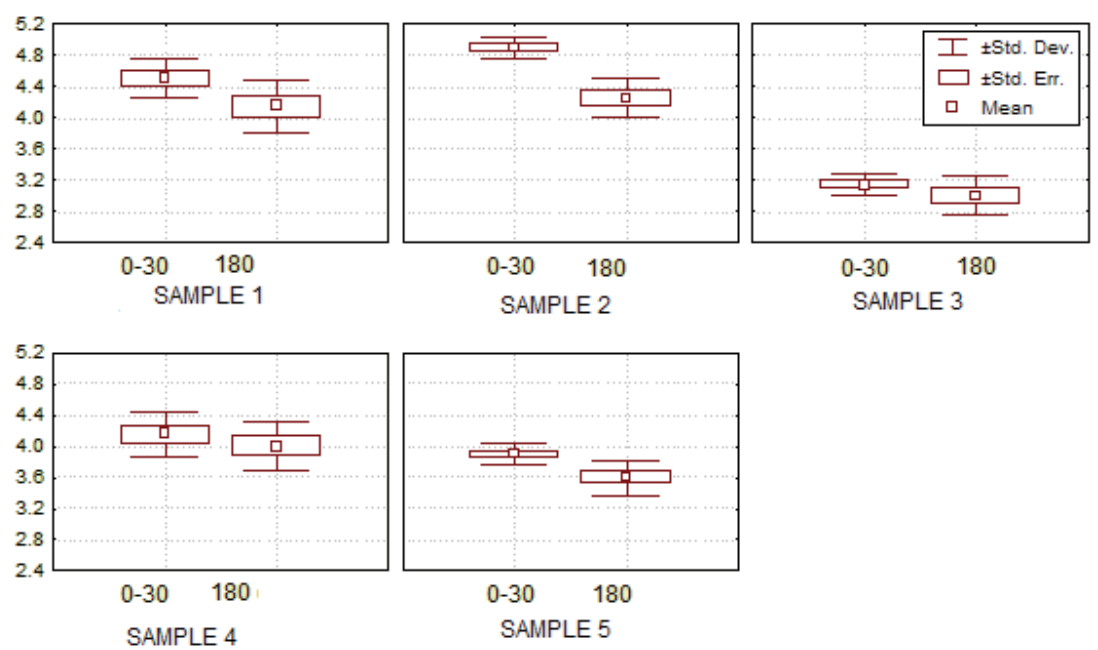

Time of keeping and storage (days)

Figure 2. Box-plots for sensory characteristic consistence/texture, i.e., spreadability.
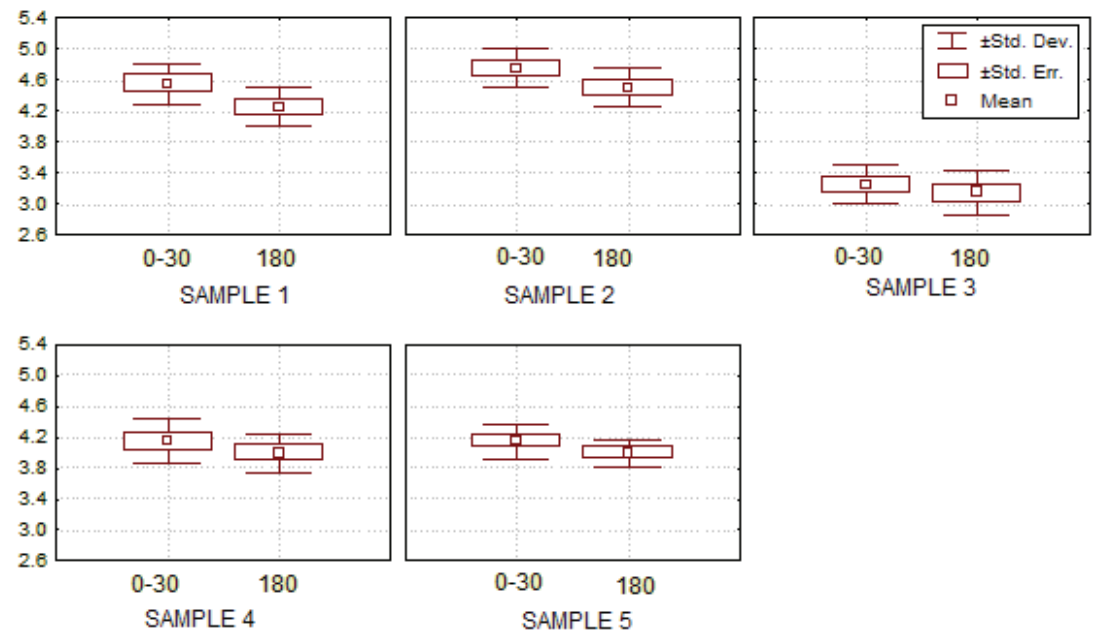

Time of keeping and storage (days)

Figure 3. Box-plots for sensory property consistence/texture - as dynamic property melting and oiliness. 

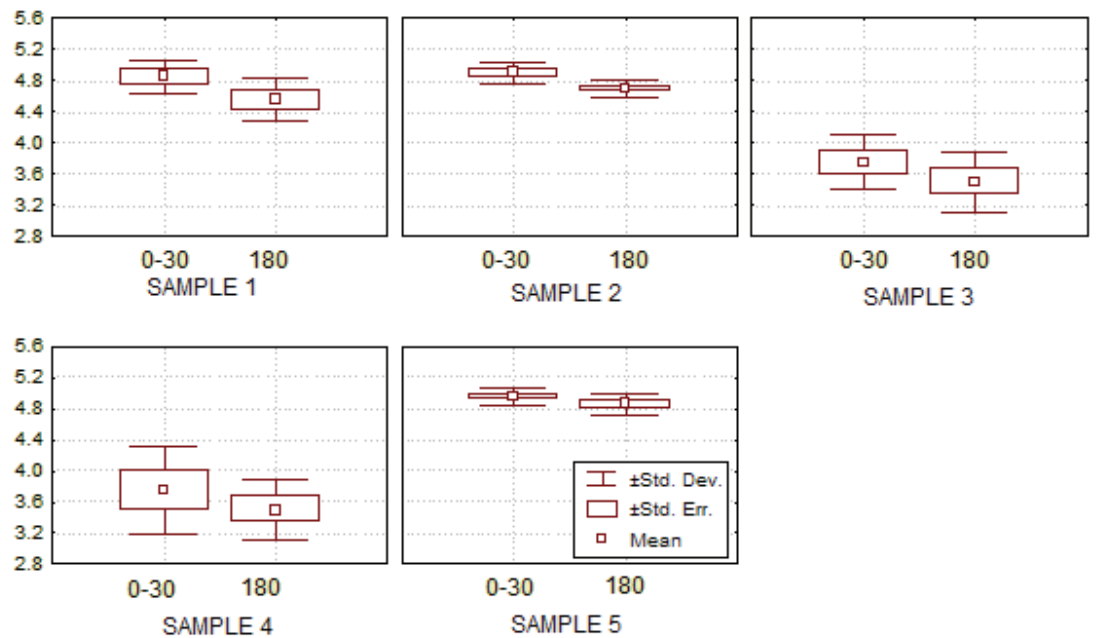

Time of keeping and storage (days)

Figure 4. Box-plots for sensory property-flavor-odor.
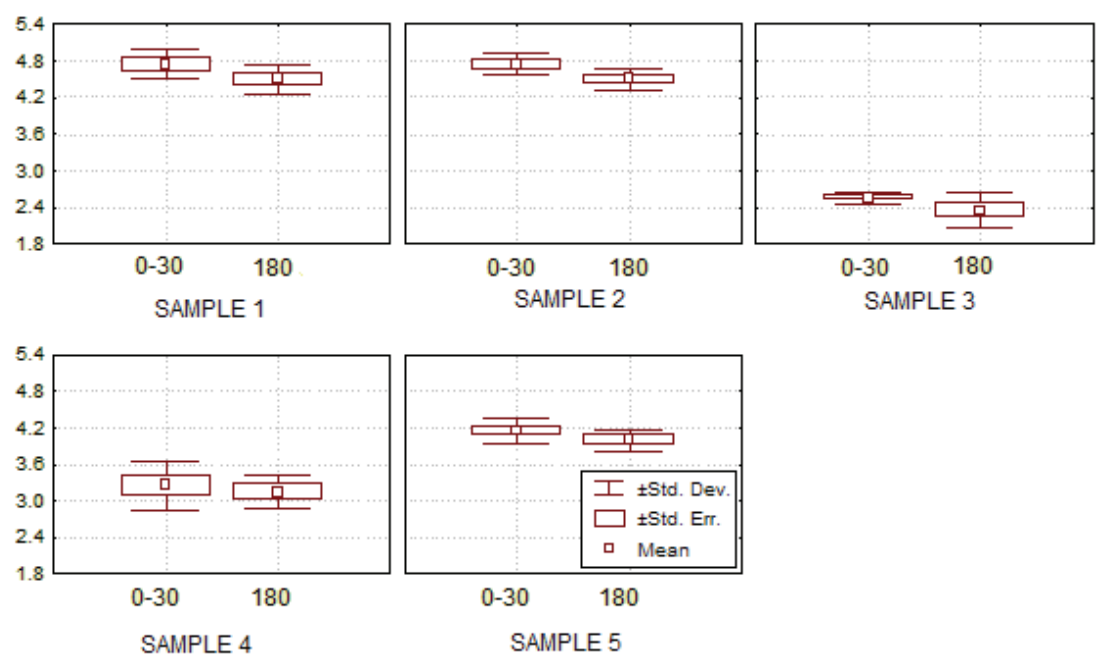

Time of keeping and storage (days)

Figure 5. Box-plots for sensory property - flavor-taste.
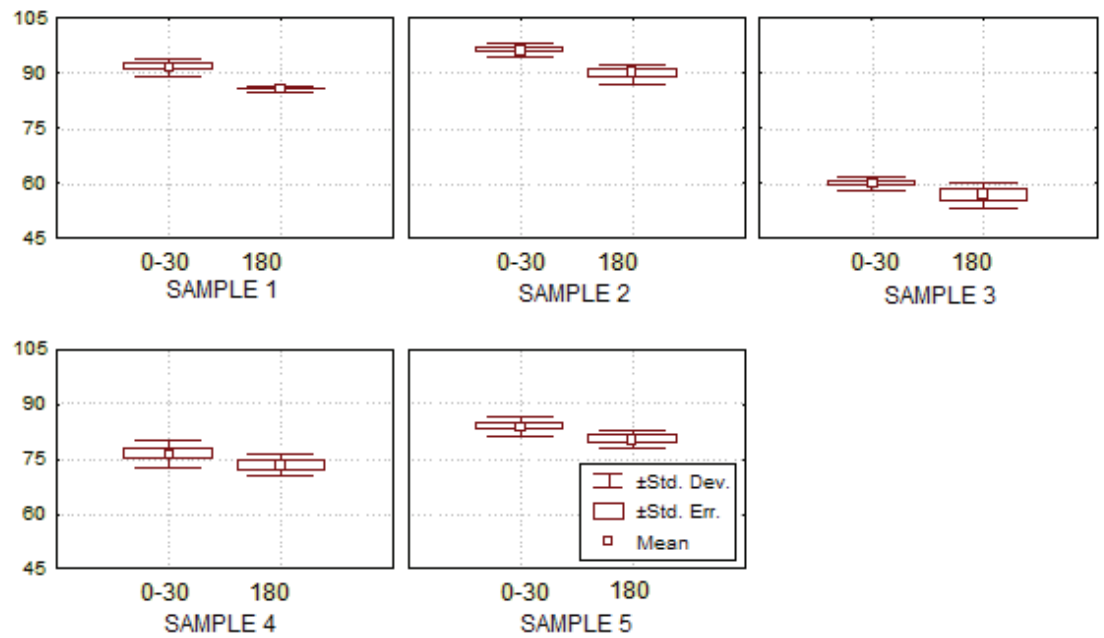

Time of keeping and storage (days)

Figure 6. Box-plots for weighted mean value. 
During the storage the sensory quality of sample 2 remained in the excellent quality category with average score $X_{m}=4.50$, or $90.00 \%$ of the maximum possible quality (Figure 6), however, very near to very good quality due to slight decrease of milky note of odor intensity (Figure 4).

The sensory quality of cocoa-milk spread (sample 3) was the lowest compared to other samples, with total score $X_{m}=3.00$, or $60 \%$ of the maximum possible quality at the first investigating period ( 0 to 30 days). Expresive surface oiliness and surface moisture was observed. Grainnes was also noticed. The sensory taste property score was significantly lower compared to other investigated samples, $X_{m}=2.55$, due to slight rancidity (Figure 5 ). This sensation was more expressed after 180 days of storage. The changes of sample 3 were visible during the oral evaluation of texture, expressed in poorer dynamic property of melting and oiliness, i.e., consistence. During storage, the sensory quality progressively deteriorated and after 180 days it was in the range of good quality category, $X_{m}=2.83$, or $56.50 \%$ (Figure 6). Certain rancidity was estimated by olfactory evaluation of flavor-odor.

Immediately after production (0 to 30 days), sample 4 was of very good sensory quality, and remained in the same category throughout the whole storage period. The flavor-taste was scored $X_{m}=3.25$ (Figure 5), due to certain change of taste (loss of milky flavor). By visual evaluation it could be noted that two phases (milk and cocoa) were not distributed equally. Minor changes of sensory characteristic - dynamic characteristic of melting and oiliness were observed orally.
The total sensory quality of sample 5 , mixture of milk and cocoa spread, after production was $X_{m}=4.19$, or $83.80 \%$ of the max possible quality (Figure 6 ). During storage up to 180 days, the sensory quality was very good $X_{\mathrm{m}}=4.02$, or $80.40 \%$. This sample gained the highest score for olfactor characteristic flavor-odor, compared to all other samples: $X_{m}=4.85$ (Figure 4), due to expressed pleasant characteristic hazelnut-like odor. Hazelnut paste contributes to pleasant taste and odor (flavor) and also improves the product nutritive value. Namely, hazelnut paste is rich in natural antioxidants and phytochemicals (phenolic compounds), with expressed antioxidative properties [29].

The orally estimated characteristic flavor-taste of sample 5 was scored somewhat lower, as the taste is pronouncedly sweet. Appearance of grainy structure was also observed, and by visual estimation it was found that the color of the milk phase was darker compared to other evaluated samples.

The results of Levene's test (Table 2 ) indicated that the data are homogenous for properties of consistence/texture, spreadability, melting-oilieness, further for flavor-taste and weighted average scores. For the properties of flavor-odor the data are non-homogenous at the level of significance $p<0.05$, and for the sensory characteristic-appearance non-homogenous at the level of significance $p<0.01$.

The results of two-factorial analysis of variance (Table 3) show that time of storage, as first observed factor, affect highly significantly $(p<0.01)$ the investigated sensory characteristics of appearance, consistence/texture-spreadability, flavor-taste and weighted mean value of scores; while significantly $(p<0.05)$

Table 2. Results of Levene's test of homogeneity of variances of samples - mixtures of milk and cocoa spreads

\begin{tabular}{lccc}
\hline \multicolumn{2}{l}{ Sensory quality characteristic } & \multicolumn{2}{c}{ Levene's test } \\
\cline { 3 - 4 } & & $F$ & 0.003 \\
Appearance & & 3.488 & 0.432 \\
Consistence/texture & Spreadability & 1.033 & 0.852 \\
& Dynamic melting characteristic - oiliness & 0.519 & 0.016 \\
Flavor & Odor & 2.645 & 0.206 \\
& Taste & 1.434 & 0.115 \\
\hline
\end{tabular}

Table 3. Analysis of variance of sensory properties of samples - mixtures of milk and cocoa spreads

\begin{tabular}{|c|c|c|c|c|c|c|c|}
\hline \multirow{2}{*}{\multicolumn{2}{|c|}{ Sensory quality characteristic }} & \multicolumn{2}{|c|}{ Time } & \multicolumn{2}{|c|}{ Composition } & \multicolumn{2}{|c|}{ Interaction } \\
\hline & & \multirow{2}{*}{$\frac{F}{11.876}$} & \multirow{2}{*}{$\frac{p}{0.001}$} & \multirow{2}{*}{$\frac{F}{133.402}$} & \multirow{2}{*}{$\frac{p}{0.000}$} & \multirow{2}{*}{$\begin{array}{c}F \\
0.536\end{array}$} & \multirow{2}{*}{$\begin{array}{c}p \\
0.709\end{array}$} \\
\hline Appearance & & & & & & & \\
\hline \multirow[t]{2}{*}{ Consistence/texture } & Spreadability & 22.021 & 0.000 & 58.150 & 0.000 & 1.806 & 0.146 \\
\hline & Dynamic melting characteristic - oiliness & 7.148 & 0.011 & 46.485 & 0.000 & 0.267 & 0.897 \\
\hline \multirow[t]{2}{*}{ Flavor } & Odor & 6.453 & 0.015 & 44.713 & 0.000 & 0.153 & 0.960 \\
\hline & Taste & 7.521 & 0.009 & 150.802 & 0.000 & 0.177 & 0.948 \\
\hline \multicolumn{2}{|c|}{ Weighted mean value of score } & 34.793 & 0.000 & 263.235 & 0.000 & 0.975 & 0.432 \\
\hline
\end{tabular}


affects the investigated sensory characteristic of consistence/texture - dynamic melting property, oiliness and flavor-odor. The second observed factor - product composition, affects highly significantly $(p<0.01)$ all the investigated sensory characteristics.

The results of LSD test for sensory characteristics of appearance for samples 1-5, mixtures of milk and cocoa spreads show that the investigated factor-time of storage up to 180 days significantly affects the mentioned characteristics $(p<0.01)$ (Table 4).

Table 4. Comparison of changes of sensory property - appearance over storage time for samples 1-5 of mixture of milk and cocoa spreads (LSD test)

\begin{tabular}{lcc}
\hline & \multicolumn{2}{c}{ Time of storage, days } \\
\cline { 2 - 3 } Time of storage, days & $0-30$ & 180 \\
\cline { 2 - 3 } & \multicolumn{2}{c}{ Means } \\
\cline { 2 - 3 } & 3.970 & 3.730 \\
\hline $0-30$ & - & 0.001 \\
180 & - & - \\
\hline
\end{tabular}

Differences in appearance exist $(p<0.01)$ between all the samples 1-5; however, between samples 1 and 5 the differences are at level $p<0.05$ and between samples 1 and 4 the differences are not significant (Table 5).

Table 5. Comparison of changes of sensory property - appearance depending on the composition for samples 1-5 of mixture of milk and cocoa spreads (LSD test)

\begin{tabular}{lccccc}
\hline & \multicolumn{5}{c}{ Sample } \\
\cline { 2 - 6 } Sample & 1 & 2 & 3 & 4 & 5 \\
\cline { 2 - 6 } & \multicolumn{5}{c}{ Means } \\
\cline { 2 - 6 } & 3.950 & 4.850 & 2.400 & 3.850 & 4.200 \\
\hline 1 & - & 0.000 & 0.000 & 0.369 & 0.028 \\
2 & - & - & 0.000 & 0.000 & 0.000 \\
3 & - & - & - & 0.000 & 0.000 \\
4 & - & - & - & - & 0.003 \\
5 & - & - & - & - & - \\
\hline
\end{tabular}

According to the results of the LSD test for sensory characteristics - consistence/texture, spreadability, for mixtures of milk and cocoa-cream spreads, the investigated factor time of storage affects the mentioned characteristics of the samples at the level of $p<0.01$ (Table 6). The differences between the visually evaluated consistence-texture, i.e., spreadability are significant for all samples $(p<0.01)$, except between samples 1 and 2, and 1 and 4, where the mentioned differences are significant at the level of $p<0.05$ (Table 7).

The consistence of spreads of exquisite sensory characteristics should be creamy, light and with no separation, i.e., migration of oil to the surface [12] during the storage, i.e., on the shelves of the super- markets during the period of 6 months. Sufficient amount of hard fat in the total fat-phase contributes to the product stability. The spread should have a firm structure, however, it should also be spreadable at room temperature. Likewise, it should not be oily, not even after keeping for a certain time at $30{ }^{\circ} \mathrm{C}[3,18]$.

Table 6. Comparison of changes of sensory property - consistence/texture - spreadability over storage time for samples 1-5 of mixture of milk and cocoa spreads (LSD test)

\begin{tabular}{lcc}
\hline & \multicolumn{2}{c}{ Time of storage, days } \\
\cline { 2 - 3 } Time of storage, days & $0-30$ & 180 \\
\cline { 2 - 3 } & \multicolumn{2}{c}{ Means } \\
\cline { 2 - 3 } & 4.120 & 3.800 \\
\hline-30 & - & 0.000 \\
\hline
\end{tabular}

Table 7. Comparison of changes of sensory property - consistence/texture - spreadability depending on the composition for samples 1-5 of mixture of milk and cocoa spreads (LSD test)

\begin{tabular}{lccccc}
\hline & \multicolumn{5}{c}{ Sample } \\
\cline { 2 - 6 } Sample & 1 & 2 & 3 & 4 & 5 \\
\cline { 2 - 6 } & \multicolumn{5}{c}{ Means } \\
\cline { 2 - 6 } & 4.325 & 4.575 & 3.075 & 4.075 & 3.750 \\
\hline 1 & - & 0.025 & 0.000 & 0.025 & 0.000 \\
2 & - & - & 0.000 & 0.000 & 0.000 \\
3 & - & - & - & 0.000 & 0.000 \\
4 & - & - & - & - & 0.000 \\
5 & - & - & - & - & - \\
\hline
\end{tabular}

The characteristic consistence/texture, including the orally evaluated dynamic melting propery and oiliness of mixtures of milk and cocoa spreads for the observed factor - storage time, affects significantly ( $p<$ 0.05 ) the analyzed property (Table 8 ). The differences in texture/melting and oiliness between samples 1 and 2 , and 4 and 5 , are not significant, however, between other samples the differences are (statistically) highly significant $(p<0.01)$ (Table 9$)$. Having in mind that different physical sensations form the consistence/ /texture of food products, this characteristic is refered by some authors as "textural properties" [30]. The texture as a sensory attribute depends on the food structure (molecular, microscopic and macroscopic), and human senses are irreplaceable in perceiving of this multiparametric attribute [31]. So, the textural characteristics are determined as: mechanical characteristics - connected with the reaction of food product on the pressure geometrical characteristics - depending on size, shape; and particles orientation in the food; other characteristics - connected with water and fat content in the food [32]. 
Table 8. Comparison of changes of sensory property - consistence/texture - dynamic characteristic of melting, oiliness over storage time for samples 1-5 of mixture of milk and cocoa spreads (LSD test)

\begin{tabular}{lcc}
\hline & \multicolumn{2}{c}{ Time of storage, days } \\
\cline { 2 - 3 } Time of storage, days & $0-30$ & 180 \\
\cline { 2 - 3 } & \multicolumn{2}{c}{ Means } \\
\cline { 2 - 3 } & 4.170 & 3.980 \\
\hline-30 & - & 0.011 \\
\hline
\end{tabular}

Table 9. Comparison of changes of sensory property - consistence/texture - dynamic characteristic of melting, oiliness depending on the composition for samples 1-5 of mixture of milk and cocoa spreads (LSD test)

\begin{tabular}{lccccc}
\hline & \multicolumn{5}{c}{ Sample } \\
\cline { 2 - 6 } Sample & 1 & 2 & 3 & 4 & 5 \\
\cline { 2 - 6 } & \multicolumn{7}{c}{ Means } \\
\cline { 2 - 6 } & 4.400 & 4.625 & 3.200 & 4.075 & 4.075 \\
\hline 1 & - & 0.052 & 0.000 & 0.006 & 0.006 \\
2 & - & - & 0.000 & 0.000 & 0.000 \\
3 & - & - & - & 0.000 & 0.000 \\
4 & - & - & - & - & 1.000 \\
5 & - & - & - & - & - \\
\hline
\end{tabular}

The sensory property flavor-odor of investigated samples - mixtures of milk and cocoa spreads changes at the level of $p<0.05$ during the storage period (Table 10). Regarding flavor-odor for the evaluated factorcomposition, on the basis of LSD test results, the differences are not significant for samples 1 and 2, 3 and 4, 1 and 5, 2 and 5; however, the differences regarding the odor, are significant at the level of $p<0.01$ for samples 1 and 3, 2 and 3, 1 and 4, 2 and 4, and for 3 and 5 , and 4 and 5 (Table 11).

Table 10. Comparison of changes of sensory property - flavorodor over storage time for samples 1-5 of mixture of milk and cocoa spreads (LSD test)

\begin{tabular}{lcc}
\hline & \multicolumn{2}{c}{ Time of storage, days } \\
\cline { 2 - 3 } Time of storage, days & $0-30$ & 180 \\
\cline { 2 - 3 } & \multicolumn{3}{c}{ Means } \\
\cline { 2 - 3 } & 4.440 & 4.220 \\
\hline $0-30$ & - & 0.015 \\
180 & - & - \\
\hline
\end{tabular}

The results of LSD test show that the factor storage time affects highly significantly $(p<0.01)$ the sensory property flavor-taste of mixtures of milk and cocoa-cream spreads (Table 12). The difference in flavor-taste between all samples are at significance level of $p<0.01$, with the exception for samples 1 and
2 , where the differences for taste are not significant (Table 13).

Table 11. Comparison of changes of sensory property - flavorodor depending on the composition for samples 1-5 of mixture of milk and cocoa spreads (LSD test)

\begin{tabular}{lccccc}
\hline & \multicolumn{5}{c}{ Sample } \\
\cline { 2 - 6 } Sample & 1 & 2 & 3 & 4 & 5 \\
\cline { 2 - 6 } & \multicolumn{7}{c}{ Means } \\
\cline { 2 - 6 } & 4.700 & 4.800 & 3.625 & 3.625 & 4.900 \\
\hline 1 & - & 0.469 & 0.000 & 0.000 & 0.152 \\
2 & - & - & 0.000 & 0.000 & 0.469 \\
3 & - & - & - & 1.000 & 0.000 \\
4 & - & - & - & - & 0.000 \\
5 & - & - & - & - & - \\
\hline
\end{tabular}

Table 12. Comparison of changes of sensory property - flavortaste over storage time for samples 1-5 of mixture of milk and cocoa spreads (LSD test)

\begin{tabular}{lcc}
\hline & \multicolumn{2}{c}{ Time of storage, days } \\
\cline { 2 - 3 } Time of storage, days & $0-30$ & 180 \\
\cline { 2 - 3 } & \multicolumn{2}{c}{ Means } \\
\cline { 2 - 3 } & 3.890 & 3.700 \\
\hline $0-30$ & - & 0.009 \\
180 & - & - \\
\hline
\end{tabular}

Table 13. Comparison of changes of sensory property - flavortaste depending on the composition for samples 1-5 of mixture of milk and cocoa spreads (LSD test)

\begin{tabular}{lccccc}
\hline & \multicolumn{5}{c}{ Sample } \\
\cline { 2 - 6 } Sample & 1 & 2 & 3 & 4 & 5 \\
\cline { 2 - 6 } & \multicolumn{7}{c}{ Means } \\
\cline { 2 - 6 } & 4.625 & 4.625 & 2.450 & 3.200 & 4.075 \\
\hline 1 & - & 1.000 & 0.000 & 0.000 & 0.000 \\
2 & - & - & 0.000 & 0.000 & 0.000 \\
3 & - & - & - & 0.000 & 0.000 \\
4 & - & - & - & - & 0.000 \\
5 & - & - & - & - & - \\
\hline
\end{tabular}

The weighted mean value of the scores for mixtures of milk and cocoa spreads changes significantly during storage (Table 14). The results of LSD test show that the differences between all samples are at significance level $p<0.01$ (Table 15).

The noticed changes of sensory properties of mixtures of milk and cocoa spreads are supported by the results of peroxide value (Figure 7 ) and of FFA content (Figure 8). The sources of contamination with heavy metals, in the confectionery products, are mostly the main ingredients [33] that are used for the production.

Besides achieving the appropriate sensory properties (appearance, colour, surface, shine, consistence and flavor), as very important parameters for the con- 
sumers, a considerable task for the confectionery industry is to obtain a healthy-sound final product. The content of lead, cadmium and copper in prepared samples of mixtures of milk and cocoa spreads is presented in Table 16.

Table 14. Comparison of changes of the weighted mean value of the scores over storage time for samples 1-5 of mixture of milk and cocoa spreads (LSD test)

\begin{tabular}{lcc}
\hline & \multicolumn{2}{c}{ Time of storage, days } \\
\cline { 2 - 3 } Time of storage, days & $0-30$ & 180 \\
\cline { 2 - 3 } & \multicolumn{2}{c}{ Means } \\
\cline { 2 - 3 } & 81.660 & 77.220 \\
\hline $0-30$ & - & 0.000 \\
180 & - & - \\
\hline
\end{tabular}

It can be noted that all analysed samples had very equable content of lead and cadmium, while the copper content varied in the broader range (from 2.168 $\mathrm{mg} / \mathrm{kg}$ for sample 2, up to $9.899 \mathrm{mg} / \mathrm{kg}$ for sample 3). However, the content of heavy metals in all investigated samples of mixtures of milk and cocoa spreadss (Table 16) is acceptably low and fulfills the demands given in the Rulebook [28] in the period up to 180 days.
Table 15. Comparison of changes the weighted mean value of the scores depending on the composition for samples 1-5 of mixture of milk and cocoa spreads (LSD test)

\begin{tabular}{lccccc}
\hline & \multicolumn{6}{c}{ Sample } \\
\cline { 2 - 6 } Sample & 1 & 2 & 3 & 4 & 5 \\
\cline { 2 - 6 } & \multicolumn{7}{c}{ Means } \\
\cline { 2 - 6 } & 88.750 & 93.100 & 58.350 & 74.900 & 82.100 \\
\hline 1 & - & 0.000 & 0.000 & 0.000 & 0.000 \\
2 & - & - & 0.000 & 0.000 & 0.000 \\
3 & - & - & - & 0.000 & 0.000 \\
4 & - & - & - & - & 0.000 \\
5 & - & - & - & - & - \\
\hline
\end{tabular}

Table 16. Content of heavy metals in the mixtures of milk and cocoa spreads

\begin{tabular}{lccc}
\hline \multirow{2}{*}{ Sample } & \multicolumn{3}{c}{ Content of heavy metals, $\mathrm{mg} / \mathrm{kg}$} \\
\cline { 2 - 4 } & Lead & Cadmium & Copper \\
\hline 1 & $0.103-0.105$ & $0.010-0.011$ & $2.258-2.285$ \\
2 & $0.104-0.107$ & $0.011-0.010$ & $2.168-2.200$ \\
3 & $0.090-0.099$ & $0.008-0.009$ & $9.886-9.899$ \\
4 & $0.101-0.108$ & $0.010-0.010$ & $5.258-5.288$ \\
5 & $0.090-0.096$ & $0.009-0.010$ & $4.479-4.496$ \\
\hline
\end{tabular}

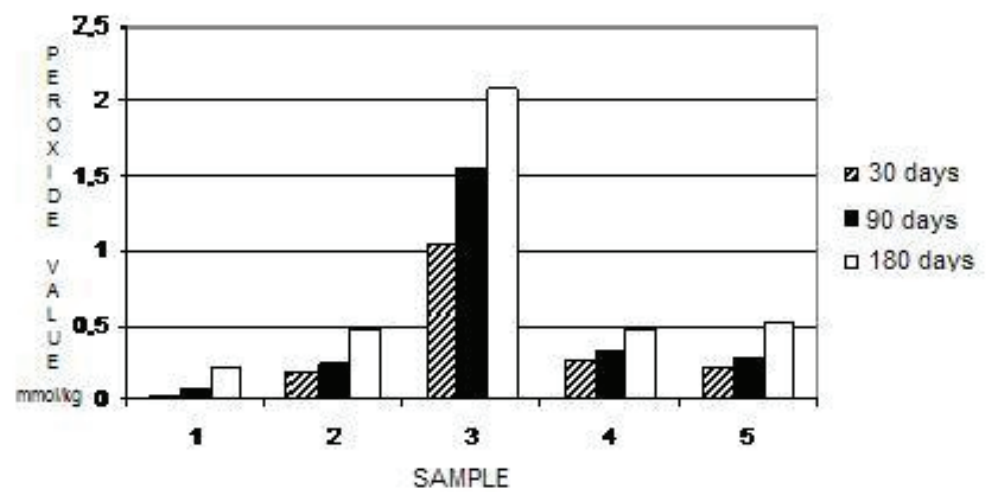

Figure 7. Change of peroxide value $(\mathrm{mmol} / \mathrm{kg})$ of mixtures of milk and cocoa-spreads during 180 days of storage.

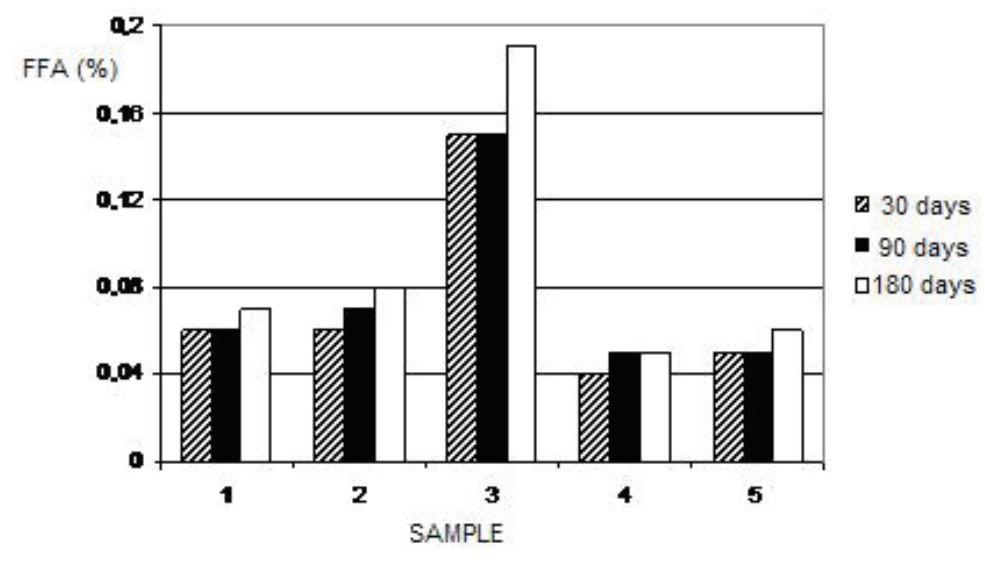

Figure 8. Change of FFA content (\% of oleic acid) of mixtures of milk and cocoa spreads during 180 days of storage. 


\section{CONCLUSION}

Based on the obtained results, the following can be concluded:

1. In semi-industrial conditions, a new quality spread product was produced, with increased content of dairy products intended firstly for children, composed of skimmed milk powder, whey powder and their combination, hydrogenated vegetable fat (FFA < $<10 \%$ ) and refined sunflower oil, with the addition of cocoa powder with reduced cocoa butter content and hazelnut, without antioxidants and preservers, with shelf-life up to 180 days.

2. 30 days after the production, spread samples 1 and 2 were of excellent, samples 4 and 5 of very good, and sample 3 of good total sensory quality.

3. After 180 days of storage, at $18-20{ }^{\circ} \mathrm{C}$, all investigated spread samples remained in the initial quality category, with the exception of sample 1, where the total sensory quality decreased by one category, due to slightly sensory texture changes.

4. According to results of two-factorial analyses of variance, it was found that the factor-storage time significantly affects the appearance, consistence/texture, spreadability, flavor-taste, while the factor-composition greatly affects all investigated quality characteristics of spreads.

5. The results of descriptive statistics show that the mean value of scores regarding the quality characteristics: appearance, consistence/texture, spreadability and dynamic melting characteristics-oilieness, was the highest for spread 2. The highest mean value for evaluated characteristic flavor-odor was for spread 5, primarily due to a hazelnut-like odor. Further, the results show the highest mean scores for flavor-dominant milky taste was gained by spreads 1 and 2 . The sensory characteristic of spread 3 were evaluated with the lowest scores, thereby causing the lowest mean scores (appearance, consistence/texture and flavor).

6. Finally, the conclusion is that the overall quality (appearance, texture/consistence and flavor) and stability of spreads depend on the choice of the main raw materials (skimmed powdered milk, whey powder and their combination) and also of their percentage ratio.

\section{Acknowledgement}

This study was funded by the Ministry of Education, Science and Technological Development of the Republic of Serbia - Project No.: 46009. The authors are sincerely grateful to the Ministry for financing and understanding.

\section{REFERENCES}

[1] Rules on quality and other requests concerning cocoaproducts, chocolate products, chocolate-alike products and creamy products (FRY Official Gazette 1/2005) (in Serbian).

[2] L. Goldoni, Cocoa-products and chocolate-alike products, Kugler, Zagreb, 2004.

[3] M. Gavrilović, The Technology of the Confectionery Products, University of Novi Sad, Faculty of Technology, Novi Sad, 2003 (in Serbian)

[4] D. Maćej, S. Jovanović, M. Barać, Milk proteins, Monograph, University of Belgrade, Faculty of Agriculture, Belgrade-Zemun, 2007 (in Serbian).

[5] J. Popov-Raljić, Lj. Stojšin, The Technology of the Confectionery Products, University of Belgrade, Faculty of Agriculture, Belgrade, 2007, pp. 49-54 (in Serbian)

[6] A. Belščak-Cvitanović, D. Komes, R. Božanić, Milk powder as raw material for the production of milk chocolate, Hrvat. čas. prehrambenu tehnol. biotehnol. i nutr. 4(3-4) (2009) 109-115.

[7] M. Carić, S. Milanović, Dried dairy products: physical and functional characteristics, Symposium "Milk and dairy products", Tara, 2005 (in Serbian).

[8] J. Laličić, Influence of the composition and time of storage on the chosen properties of quality of various types of chocolate, Ms. Thesis, University of Belgrade, Faculty of Agriculture, Belgrade-Zemun, 2007 (in Serbian).

[9] J. Popov-Raljić, V. Sikimić, Possibility of use of milk and dairy products in confectionery, Proceedings of Technical College in Pozarevac, 2007, pp. 41-49 (in Serbian).

[10] S. Jovanović, M. Barać, D. Maćej, T. Vučić, Serum proteins-technological and functional properties and possibility of use, Savremena poljoprivreda 56 (2007) 114-125 (in Serbian).

[11] T. Topalović, S. Damljanović, G. Janković, Z. Marković, Dietary Cocoa Cream Production, Acta Agric. Serb. XII(24) (2007) 77-83.

[12] M.M. Petković, B.S. Pajin, J.M. Tomić, A.M. Torbica, Z.I. Šereš, D.B. Zarić, D.M. Šoronja-Simović, Textural and sensory properties of spreads with sucrose and maltitol, Hem. Ind. 66 (2012) 385-394 (in Serbian).

[13] S. Kravić, N. Marjanović, Z. Suturović, J. Švarc-Gajić, Z. Stojanović, M. Pucarević, Determination of trans-fatty acids in chocolate products by method of gas chromatography-mass-spectrometry, Glasnik hemičara tehnologa i ekologa Republike Srpske 2 (2009) 79-83 (in Serbian).

[14] B. Pajin, Đ. Karlović, Lj. Dokić, M. Hadnađev, Characterization of creamy-spread products, Uljarstvo 37(1-2) (2006) 13-16 (in Serbian).

[15] J. Laličić, B. Rabrenović, J. Popov-Raljić, K. Pićurić-Jovanović, Possibilities of use of palm-kernel oil in confectionery, Uljarstvo 36(3-4) (2005) 35-40 (in Serbian).

[16] E. Hartig, V. Stajić, Lj. Stojšin, Use of special-purpose lipids in confectionery, $46^{\text {th }}$ conference-production and processing of oilseeds, with international participation, Petrovac, 2005, pp. 157-163 (in Serbian).

[17] M.D. Laryea, B. Biggemann, M. Funke, I. Lombeck, H.J. Bremer, Trans fatty acid content of selected brands of West German nut-nougat cream, Z. Ernahrungswiss. 27(4) (1988) 266-271. 
[18] J. Popov-Raljić, J. Laličić, R. Gorjanović, R. Romanić, Texture properties of quality of creamy products and greasy spreads, $48^{\text {th }}$ conference-production and processing of oilseeds, with international participation, Herceg Novi, 2007, pp. 213-217 (in Serbian).

[19] C.A. Chu, A.V.A. Resurreccion, Sensory profiling and characterization of chocolate peanut spread using response surface methodology, J. Sens. Stud. 20 (2005) 243-274.

[20] ISO 8586-1, Sensory Analysis-General guidance for selection, training and monitoring of assessors-Part 1: Selected assessors, 1993.

[21] ISO 8586-2, Sensory Analysis-General guidance for selection, training and monitoring of assessors-Part 2: Experts, 1994.

[22] ISO 8589, Sensory Analysis - General guidance for the design of test rooms, 1988.

[23] R. Radovanović, J. Popov-Raljić, Sensory analysis of foodstuffs, University of Belgrade, Faculty of Agriculture, Belgrade-Novi Sad, 2000/2001, CIP 641:658.526 641:001.893 (in Serbian)

[24] J. Stanković, N. Ralević, I. Ralević, Statistics with application in agriculture, Faculty of Agriculture, Belgrade, 2002, ISBN 86-387-0317-1 (in Serbian).
[25] ISO 3960, Animal and vegetable fats and oils - Determination of peroxide value, International Organization for Standardization, Geneva, 2001.

[26] ISO 660, Animal and vegetable fats and oils - Determination of acidity, International Organization for Standardization, Geneva, 2000.

[27] E. Dimić, J. Turkulov, Quality control in the technology of edible oils, University of Novi Sad, Faculty of Technology, Novi Sad, 2000, (in Serbian).

[28] Rules on quantity of pesticides, metals and metalloids and other toxic substances, chemotherapeutics, anabolic steroids and other substances that may be found in foodstuffs, FRY Official Gazette 5/1992, 11/1992 and 32/2002 (in Serbian).

[29] C. Alasavar, F. Shahidi, Natural antioxidants in tree nuts, Eur. J. Lipid Sci. Technol. 111 (2009) 1056-1062.

[30] M.C. Bourne, Texture and Viscosity of Foods, $2^{\text {nd }}$ ed., Academic Press, London, 2002.

[31] A.S. Szczesniak, Texture is a Sensory Property, Food Qual. Prefer. 13 (2002) 215-225.

[32] ISO 11036, Sensory Analysis-Methodology-Texture profile, 1994.

[33] D. Sudhir, K. Rupali, A.G. Hegde, R.M. Sharma, Lead, cadmium and nickel in chocolates and candies from suburban areas of Mumbai, India, J. Food Compost. Anal. 6 (2005) 517-522. 


\section{IZVOD}

\section{PROMENE SENZORNIH KARAKTERISTIKA I POJEDINI PARAMETRI KVALITETA MEŠAVINE MLEČNOG I KAKAO- KREM NAMAZA TOKOM SKLADIŠTENJA DO 180 DANA}

Jovanka V. Popov-Raljić ${ }^{1}$, Jovanka G. Laličić-Petronijević ${ }^{2}$, Etelka B. Dimić ${ }^{3}$, Vladimir S.Popov ${ }^{4}, V^{2}$ esna B. Vujasinović ${ }^{5}$, Ivana V. Blešić ${ }^{1}$, Milijanko J. Portić ${ }^{1}$

${ }^{1}$ Univerzitet u Novom Sadu, Prirodno-matematički fakultet, Trg D. Obradovića 3, 21000, Novi Sad, Srbija

${ }^{2}$ Univerzitet u Beogradu, Poljoprivredni fakultet, Nemanjina 6, 11080, Beograd - Zemun, Srbija

${ }^{3}$ Univerzitet u Novom Sadu, Tehnološki fakultet, Bulevar Cara Lazara 1, 21000, Novi Sad, Srbija

${ }^{4}$ Univerzitet u Novom Sadu, Poljoprivredni fakultet, Trg D. Obradovića 8, 21000, Novi Sad, Srbija

${ }^{5}$ Visoka škola strukovnih studija za menadžment i poslovne komunikacije, Mitropolita Stratimirovića 110, Sremski Karlovci, Srbija

\section{(Naučni rad)}

Primena mleka i proizvoda od mleka u tehnologiji konditorskih proizvoda (čokolada, bombonski proizvodi-karamele, mlečni krem namazi i dr.) ima za cilj povećanje hranljive vrednosti finalnog proizvoda i uticaj na pojedina senzorna svojstva kvaliteta (izgled, konzistencija/tekstura i aroma). U radu su proizvedeni uzorci mešavine mlečnog i kakao krema, novog sastava, sa povećanim udelom mlečnih delova, na kojima su, potom, ocenjene promene senzornih svojstava, određen peroksidni broj, sadržaj slobodnih masnih kiselina i sadržaj teških metala (olova, kadmijuma i bakra), tokom skladištenja do 180 dana, pri sobnoj temperaturi od $\left(18-20^{\circ} \mathrm{C}\right)$. Primenjena je analitička-deskriptivna senzorna analiza (bod sistem), uz opisivanje dominantnih svojstava (izgled-boja, oblik, sjaj površine, konzistencija-mazivost, dinamičko svojstvo topljenja, konzistentnosti usne dupljeuljavost i aroma-miris i ukus). Rezultati su statistički obrađeni primenom dvofaktorijalne analize varijanse MANOVA, LSD i Levene's testa. Na osnovu dobijenih rezultata može se konstatovati da sastav namaza (obrano mleko u prahu, surutka u prahu i njihova kombinacija, hidrogenizovana biljna mast (trans masne kiseline ispod $10 \%$ ) i rafinisano suncokretovo ulje, kakao-prah sa redukovanim sadržajem kakao maslaca i lešnik ) statistički vrlo značajno utiče na sva ocenjivana svojstva, dok vreme skladištenja, statistički vrlo značajno utiče na izgled, konzistenciju tj. mazivost i na ukus.
Ključne reči: Senzorna analiza • Krem proizvod - Peroksidni broj - Slobodne masne kiseline • Teški metali • Skladištenje 